Acta Cryst. (2002). A58 (Supplement), C156

\section{CALCULATION OF THE B-O TRIANGLE TO B-O TETRAHEDRON RATIO IN BORATES}

E. Parthe

University of Geneva Department of Inorganic Chemistry Science II, 30 Quai

E.Ansermet GENEVA 4 CH - 1211 SWITZERLAND

The ratio of the numbers of $\mathrm{BO}_{3}$ triangles and $\mathrm{BO}_{4}$ tetrahedra which make up an anion complex is frequently used for the identification of the so-called fundamental building blocks. Assuming the following bonding model this ratio can be calculated in advance from the borate composition. A covalently bound anion complex extends weak ionic bonds towards the cations. To complete its octet each $\mathrm{O}$ forms two covalent bonds either with $2 \mathrm{~B}$ or $1 \mathrm{~B}+1 \mathrm{H}$. The $\mathrm{B}$ atoms, which have no preference for triangular or tetrahedral $\mathrm{O}$ coordination, adopt a mixing ratio, expressed by (1), where all $\mathrm{O}$ atoms can have the proper number of B-O-B and/or B-O-H bonds.

$\% \Delta=4-\mathrm{A} / \mathrm{C}^{\prime} .(2-\% \mathrm{OH})$

$\% \Delta$ is the ratio of the number of triangularly coordinated $\mathrm{B}$ atoms to the total number of $\mathrm{B}$ atoms. $\mathrm{A} / \mathrm{C}^{\prime}$ is the ratio of the number of anions $(\mathrm{O}$ and/or $\mathrm{OH})$ of the anion complex to the number of central atoms (B). $\% \mathrm{OH}$ is the ratio of the number of $\mathrm{OH}$ groups bound to a central atom to the total number of $\mathrm{O}$ atoms bound to a central atom. Eq. (1) is valid in a restricted composition range where lie one quarter of all borates. 222 of these borates had been tested with eq. (1) and an agreement was found for $85 \%$ of them. A detailed account is in print with $\mathrm{Z}$. Kristallogr.

Keywords: BORATES, TRIANGLE TO TETRAHEDRON RATIO, $\mathrm{BO}_{3}$ $\mathrm{TO} \mathrm{BO}_{4}$ RATIO

Acta Cryst. (2002). A58 (Supplement), C156

MONOCLINIC SUPERSTRUCTURE OF SrMgF 4 WITH PEROVSKITE-TYPE SLABS

K. Suda ${ }^{1}$ N. Ishizawa ${ }^{1}$ B. E. Etschmann ${ }^{1}$ D. J. du Boulay ${ }^{1}$ N. Kodama ${ }^{2}$

${ }^{1}$ Tokyo Institute of Technology Materials And Structures Laboratory 4259 Nagatsuta, Midori-Ku YOKOHAMA 226-8503 JAPAN ${ }^{2}$ Akita University,Akita 010-8502,Japan

Crystals of Ce-doped $\mathrm{SrMgF}_{4}$ have been found to have a monoclinic P112 structure with doubled a and tripled c lengths with respect to the orthorhombic $\mathrm{Cmcm}$ structure previously reported in the literature. The perovskite-type slabs, composed of corner-sharing $\mathrm{MgF}_{6}$ octahedra and $\mathrm{Sr}$ atoms, are stacked along the $\mathrm{b}$ axis. The six crystallographically independent $\mathrm{MgF}_{6}$ octahedra are rotated so as to provide long periodicities along a and $\mathrm{c}$. The coordination numbers and bond distances around six crystallographically independent $\mathrm{Sr}$ atoms are slightly different in each case. Although there are no constraints among the positional parameters of the six independent $\mathrm{Sr}$ atoms in P112 1 , they align almost on a plane perpendicular to a. The $\mathrm{Mg}_{1} \mathrm{~F}_{6}$ and $\mathrm{Mg}_{4} \mathrm{~F}_{6}, \mathrm{Mg}_{2} \mathrm{~F}_{6}$ and $\mathrm{Mg}_{5} \mathrm{~F}_{6}$, and $\mathrm{Mg}_{3} \mathrm{~F}_{6}$ and $\mathrm{Mg}_{6} \mathrm{~F}_{6}$ octahedra are pairwise related by these pseudo-mirror planes defined by the $\mathrm{Sr}$ atoms. These local mirror planes are thought to originate at the high temperature phase transition from the $\mathrm{Cmcm}$ archetype.

Keywords: INORGANIC FERROELECTRIC STRUCTURE
Acta Cryst. (2002). A58 (Supplement), C156

CRYSTAL STRUCTURES OF PHASES IN THE SYSTEM CaO-K $\mathrm{K}_{2}$ $\mathbf{P}_{2} \mathbf{O}_{5}$

M. H. S. Sandstrom D. Bostrom

Department of Inorganic Chemistry Umea University UMEA 90187 SWEDEN

There are a number of elements constituting the condensed phases formed during combustion and gasification of biomass fuels. In addition to the traditionally studied major ash forming elements $(\mathrm{Ca}, \mathrm{K}, \mathrm{Na}, \mathrm{Si})$, a significant amount of $\mathrm{P}$ is contained in many biomass fuels and sludges. However, reliable identification tools such in terms of powder X-ray diffraction (XRD) patterns for many ash species containing $\mathrm{P}$ are lacking. To remedy this situation structural investigations for a number of phases in the system $\mathrm{CaO}-\mathrm{K}_{2} \mathrm{O}-\mathrm{P}_{2} \mathrm{O}_{5}$ has been initiated. The situation is complicated by the fact that many ternary compounds in the system shows several structurally close-related phase modifications. A combination of single-crystal high-temperature structures, high-temperature powder diffraction and Rietveld techniques are used to clarify the intricate phase relations.

The crystal structures of $\mathrm{CaK}_{2} \mathrm{P}_{2} \mathrm{O}_{7}$ and $\mathrm{Ca}_{10} \mathrm{~K}\left(\mathrm{PO}_{4}\right)_{7}$, formed from hightemperature melts, have been determined using single-crystal X-ray diffractometry. $\mathrm{CaK}_{2} \mathrm{P}_{2} \mathrm{O}_{7}$ crystallizes in a monoclinic space-group $\mathrm{P} 21 / \mathrm{n}$ with the cell parameters: $\mathrm{a}=9.8170(2) \AA, \mathrm{b}=5.6750(1) \AA, \mathrm{c}=13.0030(3) \AA$ and $\beta=104.218(1)^{\circ} . \mathrm{Ca}_{10} \mathrm{~K}\left(\mathrm{PO}_{4}\right)_{7}$ crystallizes in the trigonal space-group $\mathrm{R} 3 \mathrm{c}$ with

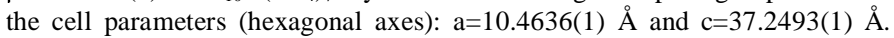
Calculated and experimental powder XRD pattern for the different phase modifications of the structures will be presented.

Keywords: PHOSPHATE, HIGH-TEMPERATURE STRUCTURE, XRD PATTERN
Acta Cryst. (2002). A58 (Supplement), C156

A COMPARATIVE TOPOLOGICAL ANALYSIS OF CRYSTAL STRUCTURES OF ANHYDROUS SIMPLE BORATES, CARBONATES AND NITRATES

$\underline{\text { Yu.A. Zakutkin }}$

Samara State University Chemistry Department Ac. Pavlov St. 1 SAMARA 443011 RUSSIA

Using the program package for multipurpose crystal-chemical analysis TOPOS the topological comparative analysis was performed for crystal structures of anhydrous inorganic salts containing triangular oxo-anions L (borates, carbonates and nitrates). The cases of topological similarity between these classes of substances and binary compounds (comprising $\mathrm{A}$ and $\mathrm{X}$ atoms) were revealed and discussed within the following scheme: $\mathrm{M} \leftrightarrow \mathrm{A}$ (or $\mathrm{X}$ ); $\mathrm{L} \leftrightarrow \mathrm{X}$ (or A). This scheme describes the representation of a salt as a quasi-binary compound composed by $\mathrm{M}$ cations and $\mathrm{L}$ anions considering as a whole. Thus the crystal structures of anhydrous salts topologically often correspond to widespread structure types based on ionic close packings: $\mathrm{NaCl}$, fluorite, $\mathrm{NiAs}$, $\alpha$-alumina. The analysis performed showed that in majority of compounds one can select ionic substructures to be built with close packing or b.c.c. motifs. The most valid crystal structure representation (both in the view of crystal structure as a net of interatomic bonds, and in respect to its representation as an ionic packing) is the selection of $\mathrm{M}$ cations and $\mathrm{L}$ anions as the main structureforming components. Increase of ion charge promotes increase of its structureforming role. Thus, it is the borate ions with the maximum charge that tend to be arranged on b.c.c. lattice with the maximum uniformity among all threedimensional frameworks. Increase of ion size also increases its structureforming role, as a rule. This phenomenon is the most clear in the case of aragonite topological type where large metal cations form the most uniform lattice with the b.c.c. topology.

Keywords: TOPOLOGY, PACKINGS, CLASSIFICATION 